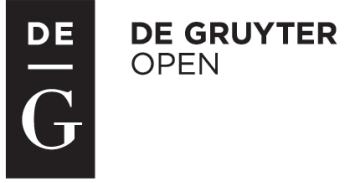

\title{
INFLUENCE OF INCREASED DIETARY SELENIUM ON GLUTATHIONE PEROXIDASE ACTIVITY AND GLUTATHIONE CONCENTRATION IN ERYTHROCYTES OF LACTATING SOWS*
}

\author{
Pavel Horký \\ Department of Animal Nutrition and Forage Production, Faculty of Agronomy, \\ Mendel University in Brno, Zemědělská 1, 61300 Brno, Czech Republic \\ Corresponding author: pavel.horky@mendelu.cz
}

\begin{abstract}
We studied the influence of different selenium (Se) levels on some parameters of the antioxidant potential of lactating sows. The experiment involved 15 sows of the Large White breed divided into 3 equal groups. The addition of Se (from Se-enriched yeast) amounted to $0.0,0.25$ and 0.50 $\mathrm{mg}$ per $\mathrm{kg}$ of diet in the control, Se1 and Se2 groups, respectively. Erythrocyte Se concentration, glutathione peroxidase (GPx) activity and reduced/oxygenated glutathione ratio were measured as some of the indicators of the sow's antioxidant status. Supplementation of Se at $0.25 \mathrm{mg} / \mathrm{kg}$ of diet increased Se concentration (by $50.0 \% ; \mathrm{P}<0.01$ ), GPx activity (by $17.0 \%: \mathrm{P}<0.05$ ) and reduced/ oxygenated glutathione ratio (by $29.7 \% ; P<0.05$ ). Addition of Se at $0.50 \mathrm{mg} / \mathrm{kg}$ of diet increased Se concentration (by $63.6 \% ; \mathrm{P}<0.01$ ), GPx activity (by $34.7 \% ; \mathrm{P}<0.01$ ) and reduced/oxygenated glutathione ratio (by 64.0\%; $\mathrm{P}<0.01)$. A significant relationship $(\mathrm{P}<0.01)$ was found between the $\mathrm{Se}$ concentrations and activity of GPx in erythrocytes from sows in the Se1 and Se2 groups ( $r=0.76$ and 0.77 , respectively). Percentage of piglets weaned/born was higher $(\mathrm{P}>0.05)$ in the $\mathrm{Se} 2$ than in the Se1 and control groups. In summary, addition of 0.25 or $0.50 \mathrm{mg} \mathrm{Se} / \mathrm{kg}$ of diet can improve antioxidant status of lactating sows, but addition of $0.25 \mathrm{mg} \mathrm{Se} / \mathrm{kg}$ may be also sufficient.
\end{abstract}

Key words: selenium, antioxidant, erythrocytes, sows, piglets

Selenium is currently perceived to be a strong antioxidant playing an irreplaceable role in the organism. Therefore, it is considered to be an essential element. Selenium forms part of the enzyme glutathione peroxidase (GPx), which participates in eliminating free radicals from the organism. High levels of free oxygen radicals lead to oxidation stress during which cells and tissues may suffer damage (Fernandez

*This work has been realised in the context of grant TP3/2013 financed by the Internal Grant Agency (IGA) of Faculty of Agronomy, Mendel University in Brno, Czech Republic. 
et al., 2008). Selenium occurs in all cells. In sows, addition of Se has been shown to favourably affect the formation of oocytes, as well as to increase the number of piglets in the litter and their vitality (Close and Cole, 2003). Thus, adding Se to the diet makes sense particularly in highly productive animals (Close and Cole, 2003). In boars, Se plays an important role in spermiogenesis (Horký et al., 2012 b). Selenium works in interaction with vitamin E, which is another highly efficient antioxidant (Zduńczyk et al., 2013). The content of Se in the organism changes depending upon the amount of that element in the ration (Kim and Mahan, 2001). Shiobara et al. (1998) had shown that addition of Se to the diet of rats significantly increased GPx activity and at the same time decreased peroxidation of lipids, as indicated by the measurement of malondialdehyde. The boundary between essential and toxic levels of Se is nevertheless very narrow and high doses of Se are toxic (Olson, 1986). Selenium toxicity manifests itself primarily by the breaking of skin derivatives, falling out of bristles, and occurrence of garlic breath (Olson, 1986). Selenium is one of the essential micronutrients that plays a specific role in terms of antioxidant defence of organism before oxygen radicals (Jancikova et al., 2012). Meanwhile, the Se content in the soils of EU countries is very low, and that is why this microelement must be added into the diet of farm animals (Kurza et al., 2010; Polakova, 2010). Zeman et al. (2006) suggested recommended dose of $0.30 \mathrm{mg}$ of selenium for sows per $\mathrm{kg}$ of diet.

The aim of the present experiment was to examine the effect of supplementing Se at various levels on the antioxidant potential of the organism in lactating sows. The partial aim of this study was to evaluate the effect of addition of different doses of selenium on reproductive performance of sows.

\section{Material and methods}

\section{Animals}

The experiment was conducted in the farrowing house of Hospodářské obchodní družstvo Jabloňov-Ruda, a farming cooperative in the Czech Republic. It included 15 sows in the period after parturition, which were divided into three equal groups $(n=5)$ equivalent according to age. The ages of the sows ranged from 2 to 3 years. All experimental sows were of the Large White breed (Sus scrofa domestica). The animals were housed individually in farrowing pens with ad libitum access to water.

The temperature of $18^{\circ} \mathrm{C}$ was maintained in the stable using controlled air conditioning. The health status of sows was monitored by a veterinary technician. Attention was paid to body temperature measured rectally first 24 hours after the birth. During the experiment, no medication was given to the sows of the experimental and control groups. After the birth, each sow (experimental and control groups) was given a single vitamin injection at a dose of $5 \mathrm{ml}$ (Duphafral MULTI, Pfizer Olot, Spain). A 1 ml contains: Retinoli Palmitas 15000 IU; Colecalciferol 7500 IU; Alphatocopherol acetate $20 \mathrm{mg}$; Thiaminum $10 \mathrm{mg}$; Riboflavinum $5 \mathrm{mg}$; Pyridoxinum 3 mg; Cyanocobalaminum 20 ppm; Nicotinamidum 35 mg; Dexpanthenolum 25 mg. 
The sows were fed a ration of $2.4 \mathrm{~kg}$ for the first three days. A $4.4 \mathrm{~kg}$ of feed mixture was given to the sows from the fifth to seventh day. From the eighth day to the weaning, the feed was submitted to all animals at a ration of $6.4 \mathrm{~kg}$. The basic feed ration contained $0.05 \mathrm{mg} \mathrm{Se} / \mathrm{kg}$ as shown in Table 1.

Table 1. Composition of the complete feed mixture for experimental sows

\begin{tabular}{lc}
\hline \multicolumn{1}{c|}{ Component } & Proportion (\%) \\
\hline Wheat & 58.80 \\
Winter barley & 20.00 \\
Soybean meal & 15.00 \\
Premix with minerals and vitamins (P3-plus PK 3.2\%) $)^{1,2}$ & 3.20 \\
Oats & 3.00 \\
\hline
\end{tabular}

${ }^{1}$ Premix with minerals and vitamins (P3-plus PK 3.2\%) did not contain added selenium.

${ }^{2}$ Supplied per kg of mixture: Supplied per kilogram of feed: 12000 IU vitamin A, 1500 IU vitamin $\mathrm{D}_{3}$, $80 \mathrm{mg}$ vitamin $\mathrm{E}, 1.8 \mathrm{mg}$ vitamin $\mathrm{K}_{3}, 1.8 \mathrm{mg}$ vitamin $\mathrm{B}_{1}, 7.7 \mathrm{mg}$ vitamin $\mathrm{B}_{2}, 3.0 \mathrm{mg}$ vitamin $\mathrm{B}_{6}, 0.4 \mathrm{mg}$ vitamin $\mathrm{B}_{12}, 15 \mathrm{mg}$ niacinamide, $0.2 \mathrm{mg}$ biotin, $0.3 \mathrm{mg}$ folic acid, $399 \mathrm{mg}$ choline chloride, $0.3 \mathrm{mg}$ bis/carbonate/tris/ hydroxide/cobaltous monohydrate (as $\mathrm{Co}$ ), $9.3 \mathrm{mg}$ copper sulphate pentahydrate (as $\mathrm{Cu}$ ), $99 \mathrm{mg}$ iron sulphate monohydrate (as Fe), 0.4 potassium iodide (as I), $45 \mathrm{mg}$ manganese monoxide (as $\mathrm{Mn}$ ), $99 \mathrm{mg}$ zinc oxide (as $\mathrm{Zn}$ ), $7.8 \mathrm{~g}$ calcium, $1.7 \mathrm{~g}$ sodium, $1.1 \mathrm{~g}$ phosphorus.

The sows were fed twice a day (morning and evening). At each feeding, the half of the total daily ration was given to the sows. The ration contained $183.2 \mathrm{~g}$ protein, $27.0 \mathrm{~g}$ fat, $9.8 \mathrm{~g}$ lysine, $7.6 \mathrm{~g}$ of calcium, $2.2 \mathrm{~g}$ of phosphorus and 14.8 MJ ME per kilogram of feed dry matter (Zeman et al., 1995).

The group of sows $(n=5)$ serving as a control group received no increase in the content of Se in their diet. The Sel group of sows ( $\mathrm{n}=5)$ was fed $0.25 \mathrm{mg} \mathrm{Se} / \mathrm{kg}$ of diet (for total intake $0.30 \mathrm{mg} \mathrm{Se} / \mathrm{kg}$ of diet). The $\mathrm{Se} 2$ group of sows $(\mathrm{n}=5)$ received supplemental $0.50 \mathrm{mg} \mathrm{Se} / \mathrm{kg}$ of diet (total intake $0.55 \mathrm{mg} \mathrm{Se} / \mathrm{kg}$ of diet). The animals received the premixed supplement with the morning feeding. The addition of Se was made through feeding Se-enriched yeast (Sel-Plex; Alltech, Lexington, KY, USA). A volumetric dispenser was used to provide precisely measured premixed doses of Se.

\section{Blood sampling}

The experiment was designed to run for 20 days. All the pigs were placed under experimental observation on the first day of lactation (after parturition). Before the start, blood samples $(10 \mathrm{ml})$ were taken from all experimental animals. The blood was subsequently sampled at 10-day intervals (i.e. on days 10 and 20 of the experiment) from the vena jugularis externa into plastic containers with heparin as anticoagulant. Blood samples always were taken $3 \mathrm{~h}$ after feeding, and within $3 \mathrm{~h}$ from the end of sampling they were transported to the laboratory in a cooling box. Erythrocytes for the required analyses were obtained through centrifugation at $2300 \mathrm{rpm}$ for 20 min using an MPW-350e centrifuge (MPW Med. Instruments, Warsaw, Poland). 
Table 2. Composition of premix for experimental sows (P3-plus PK 3.2\%)

\begin{tabular}{|c|c|}
\hline Parameter & Quanity \\
\hline Vitamin A (IU/kg) & 375.000 \\
\hline Vitamin $\mathrm{D}_{3}(\mathrm{IU} / \mathrm{kg})$ & 47.000 \\
\hline Vitamin E (mg/kg) & 2.500 \\
\hline Vitamin $\mathrm{K}_{3}(\mathrm{mg} / \mathrm{kg})$ & 57 \\
\hline Vitamin $B_{1}(\mathrm{mg} / \mathrm{kg})$ & 57 \\
\hline Vitamin $B_{2}(\mathrm{mg} / \mathrm{kg})$ & 240 \\
\hline Vitamin $\mathrm{B}_{6}(\mathrm{mg} / \mathrm{kg})$ & 95 \\
\hline Vitamin $B_{12}(\mathrm{mg} / \mathrm{kg})$ & 1.4 \\
\hline Niacinamide $(\mathrm{mg} / \mathrm{kg})$ & 470 \\
\hline Biotin (mg/kg) & 7.5 \\
\hline Folic acid (mg/kg) & 9.4 \\
\hline Choline chloride (mg/kg) & 12.470 \\
\hline Bis/carbonate/tris/hydroxide/cobaltous monohydrate (as $\mathrm{Co})$ (mg/kg) & 10 \\
\hline Copper sulphate pentahydrate (as $\mathrm{Cu})(\mathrm{mg} / \mathrm{kg})$ & 290 \\
\hline Iron sulphate monohydrate (as $\mathrm{Fe})(\mathrm{mg} / \mathrm{kg})$ & 3.100 \\
\hline Potassium iodide (as I) (mg/kg) & 14 \\
\hline Manganese monoxide (as $\mathrm{Mn})(\mathrm{mg} / \mathrm{kg}$ ) & 1.410 \\
\hline Zinc oxide (as Zn) (mg/kg) & 3.100 \\
\hline Calcium (g/kg) & 220 \\
\hline Sodium chloride (as Na) (g/kg) & 55 \\
\hline Monocalcium phosphate (as $\mathrm{P})(\mathrm{g} / \mathrm{kg})$ & 33 \\
\hline
\end{tabular}

The stated data was obtained on the basis of certified values (Biofaktory, Prague, Czech Republic).

\section{Dietary Se content determination}

The content of Se in the diet was determined by atomic absorption spectroscopy. The $0.5 \mathrm{~g}$ quantity of homogenized sample was mineralized in a mix of nitric acid and hydrogen peroxide using the ETHOS One microwave digestion system (Milestone, Sorisole, Italy). After decomposition of the sample, demineralized water was added to the solution to a total volume of $25 \mathrm{ml}$. The concentration of elements in the prepared solution was determined using a high-resolution ContrAA 700 atomic absorption spectrometer with a continuum radiation source (Analytik Jena, Jena, Germany). The wavelength used was $196.026 \mathrm{~nm}$.

\section{Glutathione peroxidase (GPx) determination}

The Glutathione Peroxidase Cellular Activity Assay Kit (Sigma-Aldrich, St. Louis, MO, USA) was used for the GPx assay. Reagent R1 at a volume (erythrocytes) of $260 \mu \mathrm{l}(0.3 \mathrm{mM}$ NADPH reagent in GPx buffer) was pipetted into a plastic cuvette. Subsequently, $10 \mu \mathrm{l}$ of sample was added. After mixing, reagent R2 at a volume of $30 \mu \mathrm{l}$ ( $3 \mathrm{mM}$ tert-butyl hydroperoxide) was added into the cuvette, which started the reaction. The decrease in absorbance was measured at $340 \mathrm{~nm}$ using the kinetic program for $2 \mathrm{~min}$ and $6 \mathrm{~s}$. The spectrophotometer calculated the GPx activity according to the calibration curve. 


\section{Reduced (GSH) and oxidized (GSSH) glutathione determination}

GSH and GSSH were determined (in erythrocytes) using high-performance liquid chromatography with electrochemical detection. This system consisted of two ESA Model 582 chromatographic pumps with operating range 0.001-9.999 $\mathrm{ml} . \mathrm{min}^{-1}$ (ESA Laboratories, Chelmsford, MA, USA), a Zorbax eclipse AAA C18 reverse phase chromatographic column $(150 \times 4.6$; particle size $3.5 \mu \mathrm{m})$ from Agilent Technologies (Santa Clara, CA, USA), and a Model 5600A 12-channel CoulArray electrochemical detector (ESA Laboratories). The detector is composed of three continuous analytical compartments (Model 6210, ESA Laboratories). Each compartment contains four analytical cells. One analytical cell contains two reference (hydrogen palladium) electrodes, two auxiliary and one porous, graphite working electrode. The electrochemical detector utilizes a temperature-regulated control module. The sample $(20 \mu \mathrm{l})$ was injected automatically using an auto-sampler (Model 542, ESA Laboratories) with a built-in temperature-controlled cavity for the column. During the analysis, the samples were held in a carousel at $8^{\circ} \mathrm{C}$. The column temperature was thermostatically maintained at $32^{\circ} \mathrm{C}$. Mobile phase flow-through was $1 \mathrm{ml} \cdot \mathrm{min}^{-1}$. The mobile phase consisted of A: trifluoro-acetic acid $(80 \mathrm{mM})$ and B: $100 \%$ Met$\mathrm{OH}$. The substances were eluted according to the following linear ascending gradient: $0-1 \min (3 \%$ B), $1->2 \min (10 \%$ B), 2->5 $\min (30 \% \mathrm{~B})$ and $5-6 \min (98 \% \mathrm{~B})$. Detection of the separated substances occurred at an applied potential of $900 \mathrm{mV}$. The duration of a single analysis was $20 \mathrm{~min}$.

\section{Se determination in erythrocytes}

Determination of Se in erythrocytes by differential pulse voltammetry was performed with a 797 VA Computrace instrument connected to an 889 IC Sample Center (Metrohm, Herisau, Switzerland), using a standard cell with three electrodes. The working electrode was a hanging mercury drop electrode with a drop area of $0.4 \mathrm{~mm}^{2}$. The reference electrode was $\mathrm{Ag} / \mathrm{AgCl} / 3 \mathrm{M} \mathrm{KCl}$ and the platinum electrode was an auxiliary. The analysed samples were deoxygenated prior to measurements by purging with argon (99.999\% pure). Supporting electrolyte consisted of $0.128 \mathrm{M}$ ammonium sulphate, $0.123 \mathrm{mM}$ copper sulphate and sulphuric acid (to adjust $\mathrm{pH}$ to 2.2). The supporting electrolyte was changed after each analysis. The parameters of the measurement were as follows: initial potential $-0.4 \mathrm{~V}$, end potential $-0.9 \mathrm{~V}$, deoxygenating time with argon $120 \mathrm{~s}$, accumulation time $200 \mathrm{~s}$, deposition potential $-0.6 \mathrm{~V}$, time interval $0.05 \mathrm{~s}$, voltage step $6 \mathrm{mV}$, pulse amplitude $30 \mathrm{mV}$, volume of injected sample $20 \mu \mathrm{l}$, measurement cell volume $2 \mathrm{ml}(20 \mu \mathrm{l}$ sample $+1980 \mu \mathrm{l}$ electrolyte $)$.

\section{Statistics}

The data were processed statistically using STATISTICA.CZ, version 10.0 (Czech Republic). Results are expressed as mean \pm standard deviation (SD). Statistical significance was determined by examining the basic differences between groups and among individual samples using ANOVA and Scheffé's test (two-way analysis) for the parameters Se, GPx, GSH, GSSH and number of born versus weaned piglets. Differences with $\mathrm{P}<0.05$ were considered significant. Dependence between Se content and GPx activity was expressed by means of a linear equation and correlation coefficient $\mathrm{R}$. 


\section{Results}

No health problems were observed in the experimental animals during the experiment. Tables 3 and 4 present the measured values for Se, GPx, GSH and GSSH in erythrocytes by group and day.

No significant differences between days were found when measuring the erythrocyte Se content in the control group. The $\mathrm{Se} 1$ group of sows, by contrast, exhibited Se levels in erythrocytes that were higher by $43.9 \%(\mathrm{P}<0.01)$ and $50.0 \%(\mathrm{P}<0.01)$ on days 10 and 20, respectively. Compared with the initial sampling, the Se 2 group of animals exhibited Se content on days 10 and 20 that was higher by $54.0 \%(\mathrm{P}<0.01)$ and $63.6 \%(\mathrm{P}<0.01)$, respectively. There were significant differences in the levels of Se in erythrocytes from day 10 to day 20 between the control group and experimental group Se1, at $61.6 \%(\mathrm{P}<0.01)$ and $65.1 \%(\mathrm{P}<0.01)$, respectively. A similar difference in growth was observed also between the control group and experimental group Se2, where the difference in Se concentration had grown as of day 10 to $62.2 \%(\mathrm{P}<0.01)$ and by the experiment's end to $66.8 \%(\mathrm{P}<0.01)$.

The second monitored indicator was glutathione peroxidase (GPx), the level of which directly relates to the amount of Se in the organism. The control group of animals exhibited no statistically significant difference between the three samplings, although between the first and second and the first and third samplings GPx did rise by $2.9 \%$ and $6.7 \%$, respectively. The experimental group of animals, Se1 $(0.25 \mathrm{mg}$ $\mathrm{Se} / \mathrm{kg}$ of diet), exhibited an increase in GPx activity by $9.1 \%$ on day 10 and by the end of the experiment (day 20) the increase was $17.1 \%(\mathrm{P}<0.05)$. The experimental group, $\mathrm{Se} 2(0.50 \mathrm{mg} \mathrm{Se} / \mathrm{kg}$ of diet), showed an increase in GPx activity on day 10 of $24.2 \%(\mathrm{P}<0.01)$ while the total increase at the end of the experiment came to $34.7 \%$ $(\mathrm{P}<0.01)$ versus the first sampling. At first sampling there had been no significant differences between the experimental groups.

On days 10 and 20, group Se1 had significantly higher levels of GPx versus the control group, at $9.2 \%(\mathrm{P}<0.01)$ and $12.9 \%(\mathrm{P}<0.01)$, respectively. Significant differences were also found in comparing experimental group $\mathrm{Se} 2$ with the control group. On day 10 of the experiment the difference in GPx level was $21.7 \%(\mathrm{P}<0.01)$. Similar growth could be seen at the end of the experiment, by which time the difference had increased to $27.2 \%(\mathrm{P}<0.01)$.

Reduced glutathione (GSH) and its oxygenated form (GSSH) are important indicators for monitoring the antioxidant capacity of the organism. The control group of animals exhibited no significant changes in GSH, although at the end of the experiment the GSH concentration was $17.6 \%$ higher than at the initial sampling. In the Se1 group, the GSH concentration grew throughout the experiment - by $24.1 \%$ on day $10(\mathrm{P}<0.01)$ up to $33.3 \%$ on day $20(\mathrm{P}<0.01)$. In the $\mathrm{Se} 2$ group, the GSH level increased significantly by $65.5 \%(\mathrm{P}<0.01)$ and $68.7 \%(\mathrm{P}<0.01)$ on days 10 and 20 , respectively, as compared with the first sampling. A comparison of the control and Sel experimental groups showed significant growth in the concentration of GSH on days 10 and 20, with the differences between the two groups on those days reaching $30.0 \%(\mathrm{P}<0.01)$ and 29.6\% $(\mathrm{P}<0.01)$, respectively. Experimental group Se2 exhibited higher concentrations of GSH in comparison to the control group at the second and third samplings of $76.3 \%(\mathrm{P}<0.01)$ and $68.4 \%(\mathrm{P}<0.01)$, respectively. 


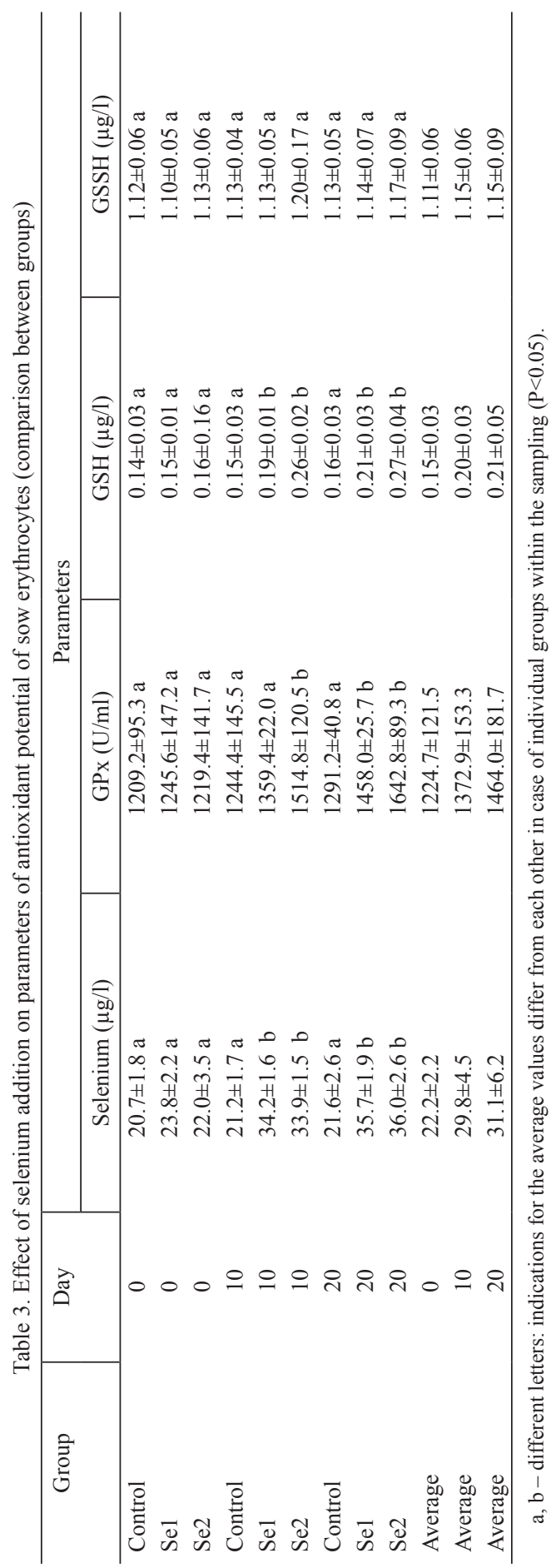




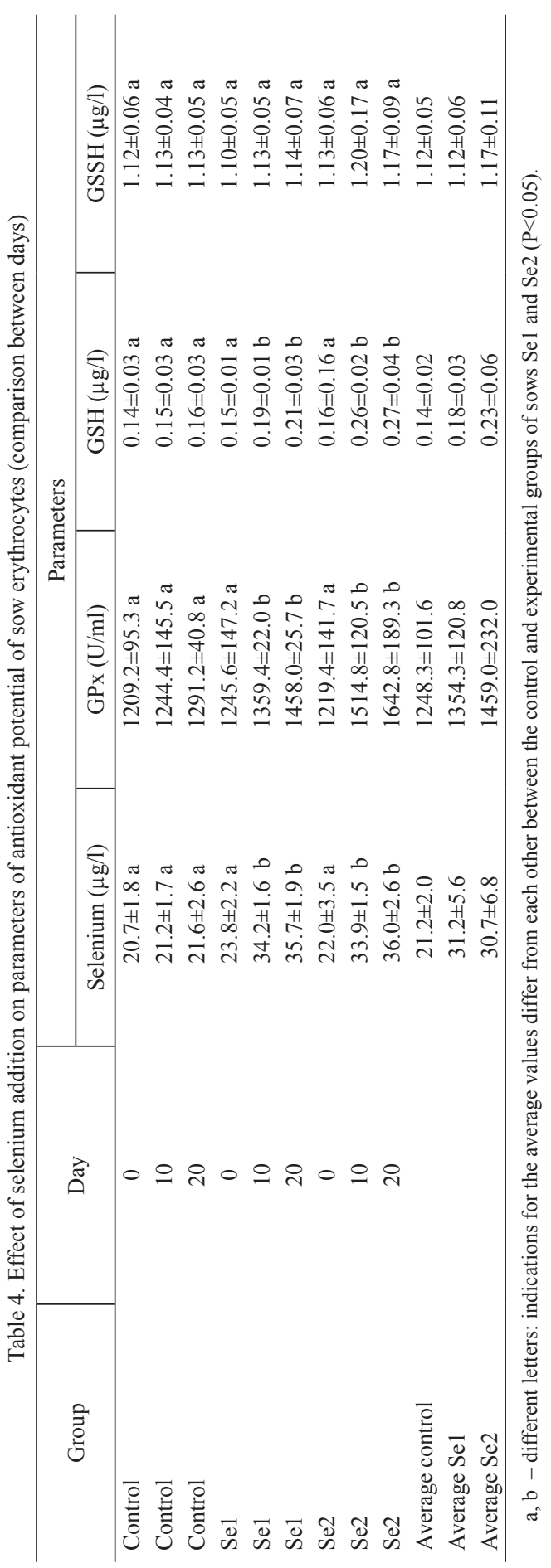


No significant differences in GSSH levels were recorded within the experimental groups, and there also were no significant differences in GSSH levels found between the control and experimental groups.

In our trial, we further assessed the correlation between Se content and GPx activity (Figures 1A, 1B and 1C). In the control group there was no significant correlation between GPx activity and the concentration of Se. Both experimental groups, by contrast, showed significant dependence. In the $\mathrm{Se} 1$ group $(\mathrm{r}=0.76$, significance level $\mathrm{P}<0.01)$, the GPx activity increased by $15.9 \mathrm{U} / \mathrm{ml}$ with each $1 \mu \mathrm{g}$ increase in Se/1. A similar significant dependence $(\mathrm{P}<0.01)$ was recorded for $\mathrm{Se} 2$ group $(\mathrm{r}=0.77)$, where GPx activity increased by $25.9 \mathrm{U} / \mathrm{ml}$ with each $1 \mu \mathrm{g}$ increase in $\mathrm{Se} / \mathrm{l}$.

A
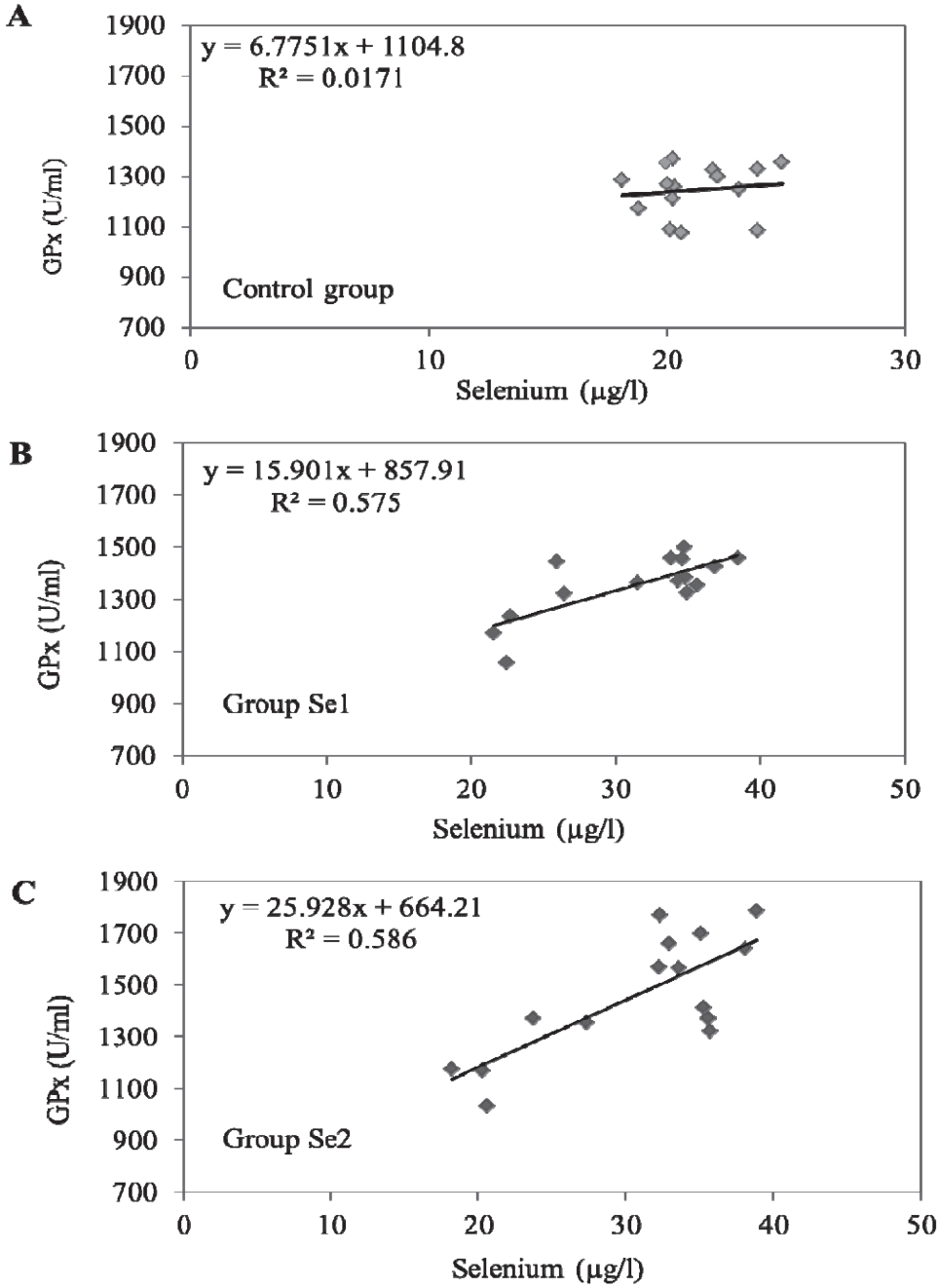

Figure 1. Relationship between the amount of selenium in erythrocytes and GPx activity in the control group (A), group Se1 (B) and group Se2 (C) 
To complete the findings, reproductive indicators (the numbers of born and weaned piglets) were evaluated. In the control group, $16.9 \%$ fewer piglets were weaned than were born. The experimental group Se1 had $21.7 \%$ fewer weaned piglets than the number at birth, and experimental group Se 2 weaned 9.5\% fewer piglets than were born. These differences between the groups were not statistically significant (Table 5).

The GSH/GSSH ratio is itself very important in evaluating the antioxidant potential of the organism. Although in the control group this ratio was $16.4 \%$ higher at day 20 in comparison with the day before launching the experiment, this change was not statistically significant (Figure 2). In the Se1 group of animals, the ratio had increased by $20.9 \%(\mathrm{P}<0.01)$ as of day 10 and by $27.9 \%(\mathrm{P}<0.05)$ by the end of the experiment. The GSH/GSSH ratio for the Se2 group of sows had increased by $59.3 \%$ $(\mathrm{P}<0.01)$ on day 10 and by $64.0 \%(\mathrm{P}<0.01)$ on day 20 . A comparison of the groups revealed a significant difference between the control and $\mathrm{Se} 1$ groups of sows on days 10 and 20 at $28.9 \%(\mathrm{P}<0.01)$ and $28.8 \%(\mathrm{P}<0.01)$, respectively. Similar development could be seen between the control and Se2 groups, where the average GSH/GSSH levels for Se2 were significantly higher, at 68.2\% $(\mathrm{P}<0.01)$ and $61.3 \%(\mathrm{P}<0.01)$, respectively, for the second and third samplings.

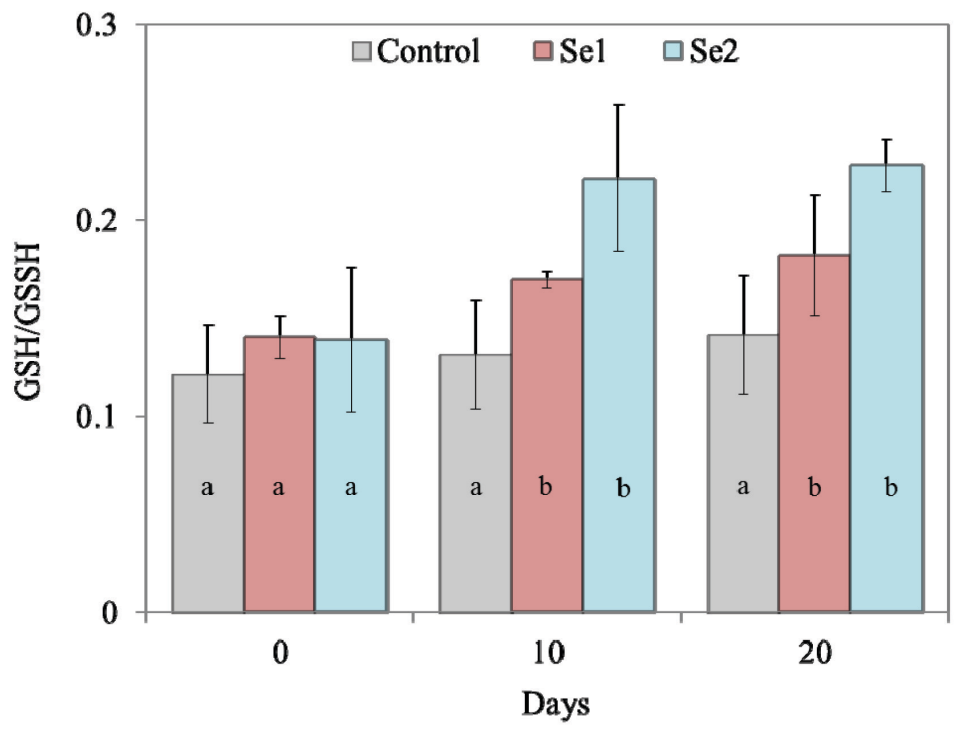

$\mathrm{a}, \mathrm{b}$ - different letters: indications for the average values differ from each other in case of individual groups within the sampling $(\mathrm{P}<0.05)$ 
Table 5. Influence of varying levels of supplemental selenium on sow reproductive indicators

\begin{tabular}{l|c|c|c}
\hline \multirow{2}{*}{ Group } & \multirow{2}{*}{ Sows } & \multicolumn{2}{c}{ Piglets } \\
\cline { 3 - 4 } Control & 1 & born & weaned \\
& 2 & 5 & 5 \\
& 3 & 13 & 12 \\
& 4 & 9 & 6 \\
Average & 5 & 15 & 13 \\
Se1 & & 13 & $9.2 \pm 3.6$ \\
& 6 & $11.0 \pm 4.0$ & 11 \\
& 7 & 14 & 11 \\
& 8 & 12 & 8 \\
& 9 & 11 & 8 \\
Average & 10 & 12 & $9.4 \pm 1.5$ \\
Se2 & & 11 & 12 \\
& 11 & $12.0 \pm 1.2$ & 11 \\
& 12 & 12 & 11 \\
& 13 & 13 & 13 \\
Average & 14 & 12 & 10 \\
\hline
\end{tabular}

\section{Discussion}

Zhan et al. (2011) arrived at the conclusion from their experiment that the addition of $0.3 \mathrm{mg} \mathrm{Se} / \mathrm{kg}$ of diet in organic form (for a period of 90 days) significantly increased the concentrations of $\mathrm{Se}(\mathrm{P}<0.05)$ and GPx $(\mathrm{P}<0.05)$ in the milk of experimental sows. In another experiment, lasting 4 months, breeding boars received a diet with the addition of $0.3 \mathrm{mg}$ or $0.6 \mathrm{mg} \mathrm{Se} / \mathrm{kg}$ of diet in organic or inorganic form. Boars given $0.6 \mathrm{mg}$ Se in organic form showed significantly higher $(\mathrm{P}<0.01)$ Se level in the ejaculate. The level of GPx enzyme also was increased $(\mathrm{P}<0.01)$. The $\mathrm{GSH} / \mathrm{GSSH}$ ratio for the group of pigs given $0.6 \mathrm{mg} \mathrm{Se} / \mathrm{kg}$ of diet was higher by $55 \%$ $(\mathrm{P}<0.05)$ (Horký et al., 2012 a). As our results indicate, supplementing Se even for a much shorter time is sufficient to increase the anti-oxidation capacity of pigs. As early as 10 days after the start of the experiment, significantly higher GPx activity and Se level were detected in erythrocytes of the Se1 and Se2 sow groups. From this finding it can be suggested that supplemental Se in the amount of $0.25 \mathrm{mg} / \mathrm{kg}$ of diet is sufficient to improve the anti-oxidation status of sows while increasing that dose to $0.5 \mathrm{mg} \mathrm{Se} / \mathrm{kg}$ of diet could be inefficient.

Marin-Guzman et al. (1997) has added $0.5 \mathrm{mg} \mathrm{Se} / \mathrm{kg}$ in organic form to the diet of experimental boars. The control group had no dietary increase in Se. This research team came to results similar to ours. GPx activity has increased significantly in ejaculate $(\mathrm{P}<0.01)$ and seminal dose plasma $(\mathrm{P}<0.01)$ in the experimental group of boars. In the total ejaculate, the Se concentration was more than four times higher 
$(\mathrm{P}<0.01)$ in the experimental group of animals. Our research displayed similar results, although the increase of GPx and of Se concentration was not as marked as in the experiment performed by Marin-Guzman et al. It is possible that ejaculate is more endangered by the effects of free radicals than in case of the erythrocytes and therefore the levels of concentrations of GPx and Se are increasing. Mahan et al. (2004) has demonstrated that the addition of Se in organic form (selenium-enriched yeast) significantly increased the content of this element in tissues, blood plasma, and the milk of short-fed pigs and sows as compared with an inorganic Se source (sodium selenite). In our experiment there also occurred a significant increase of the Se concentration in blood (erythrocytes), although it was not possible to compare which source of this element (organic or inorganic) has the greater anti-oxidation potential. This may be a subject for further research. In the experiment on rats (Sochor et al., 2012) higher GSH and GPx activity was recorded after the addition of $1.5 \mathrm{mg}$ of organic-source Se per kilogram of diet as compared with the same dose of inorganic selenium. It is apparent from this observation that even supplementing $1.5 \mathrm{mg}$ of selenium can increase the anti-oxidation potential of animals while not causing symptoms of toxicity. Pechova et al. (2012) compared two groups of goats. The experimental group received $0.3 \mathrm{mg} \mathrm{Se} / \mathrm{kg}$ of diet (from Se-enriched yeast). The control group did not receive any addition of Se to the ration. After 6 weeks of the experiment, the blood concentration of selenium was 3.5 times higher $(\mathrm{P}<0.01)$ in the experimental group than in the control group. In our experiment, Se in erythrocytes increased in the $\mathrm{Se} 2$ group of sows by $50 \%$. It is possible that if the experiment lasted longer than 20 days the Se concentration in the erythrocytes would have been higher. This also suggests that lactating sows may transfer significant amounts of Se to milk. It was found that the addition of organic Se to the diet $(0.30 \mathrm{mg} / \mathrm{kg})$ increased 2.5-fold the concentration of Se in sow milk (Mahan and Peters, 2004). The mutual correlation between the amount of Se in the organism and GPx was documented also in a study published by Jarome-Morais et al. (2012), in which they compared a group of human males with prostate cancer. These patients also showed decreased GPx $(\mathrm{r}=-0.67)$ with the decreasing concentration of Se in the body. Gresakova et al. (2013) offered two forms of Se to rams (yeast-bound selenium and sodium selenite). As we carried out in our study, these researchers similarly observed a mutual relationship between Se and GPx in the blood of these animals. Moreover, they found that the blood Se content increased by $58 \%$ more $(\mathrm{P}<0.001)$ in the group receiving the organic form than in that receiving the inorganic form. In the monitoring of GPx, no difference was found between whether the organic or inorganic form was used. If we compare our results with those of these authors, it is apparent that the addition of Se significantly correlates with the amount of GPx in erythrocytes.

In evaluating reproduction parameters, Mahan and Peters (2004) have observed a significant increase in the number of piglets born live and weaned $(\mathrm{P}<0.05)$ when $\mathrm{Se}$ was supplemented in organic form at the rate of $0.15 \mathrm{mg} / \mathrm{kg}$ of diet. This finding has not been confirmed in our observation. In our experiment, the percentage of piglets weaned/born was higher, but not significantly, in the $\mathrm{Se} 2$ compared to the control and Se1 groups. The studies with the addition of $0.30 \mathrm{mg} \mathrm{Se} / \mathrm{kg}$ to sow's diet demonstrated a significant increase in the number of weaned piglets (Hu et al., 2011), as 
well as no effect on this parameter (Mohan and Kim, 1996). As is apparent from the mixed findings described above, all clear conclusions cannot be drawn concerning potentially improved reproduction. It would be useful to test the influence of Se on reproduction indicators in sows over a longer time interval and the higher number of sows.

\section{Conclusions}

The addition of selenium at 0.25 and $0.50 \mathrm{mg} / \mathrm{kg}$ of diet significantly increased Se content, GPx activity, reduced glutathione, and the reduced/oxygenated glutathione ratio. Significant positive correlations were found between Se content and the GPx activity in erythrocytes from sows of Se1 and Se2 groups. It may be suggested that the addition of $0.25 \mathrm{mg} / \mathrm{kg}$ and $0.50 \mathrm{mg} / \mathrm{kg}$ Se to the diet improved the antioxidant potential of lactating sows. Percentage of piglets weaned/born was higher, but not significantly, in Se2 than in the control and Se1 groups. In order to conclude the influence of Se supplementation on reproductive performance, the experiment should be repeated with a larger number of sows. As the effect of Se addition at the 0.25 and $0.50 \mathrm{mg} / \mathrm{kg}$ was similar, it seems unnecessary to recommend supplementing higher than $0.25 \mathrm{mg} \mathrm{Se} / \mathrm{kg}$ to the diet for lactating sows.

\section{Acknowledgements}

This project was funded from grants and IGA TP 2/2014: Effect of specifically positive additives in animal nutrition on animal products quality and environment preservation during forage production and NAZVA QI111B044: Comprehensive strategy for decreasing a negative impact of Fusarium spp. toxicogenic fungi infection in cereals and their derivated products.

\section{References}

C l o s e W.H., C o 1 e D.J.A. (2003). Minerals. In: Nutrition of Sows and Boars, Close W.H., Cole D.J.A. (eds). Nottingham University Press, Nottingham, UK, pp. 97-124.

F ernandez L.D., Medrano A., Arenas E., Viguares V.G., Garcia A. (2008). The effect of selenium supplement in diet of young boars on semen quality, antioxidant enzymatic activity and lipid peroxidation. Theriogenology, 70, pp. 1386.

Gresakova L., Cobanova K., Faix S. (2013). Selenium retention in lambs fed diets supplemented with selenium from inorganic or organic sources. Small Rumin. Res., 111: 76-82.

Horký P., Jancikova P., Sochor J., Hynek D., Chavis G.J., Ruttkay-Nedecky B., Carne i N., Zitka O., Ze ma n L., A d a m V., K i z e k R. (2012 a). Effect of organic and inorganic form of selenium on antioxidant status of breeding boars ejaculate revealed by electrochemistry. Int. J. Electrochem. Sci., 7: 9643-9657.

H o rký P., Ja n cikova P., Z e man L. (2012 b). The effect of a supplement of chromium (picolinate) on the level of blood glucose, insulin activity and changes in laboratory evaluation of the ejaculate of breeding boars. Acta Univ. Agric. Silvic. Mendel. Brun., 16: 149-156.

$\mathrm{Hu}$ H.J., Wang M., Zh an X.A., Li X., Z h a n R.Q. (2011). Effect of different selenium sources on productive performance, serum and milk Se concentrations, and antioxidant status of sows. Biol. Trace Elem. Res., 142: 471-480.

Jan c i k ova P., Horký P., Z e m a n L. (2012). The effect of feed additive containing vitamins and trace elements on the elements profile and growth of skin derivatives in horses. Ann. Anim. Sci., 3: 381-391. 
J a r o m e-Mora is A., Wright M.E., Li u R., Yang W.C., J a c k s o n M.I., C o m b s G.F., D i a mon d A.M. (2012). Inverse association between glutathione peroxidase activity and both selenium-binding protein 1 levels and Gleason score in human prostate tissue. Prostate, 72: 1006-1012.

K i m Y.Y., Mahan D.C. (2001). Prolonged feeding of high dietary levels of organic and inorganic selenium to gilts from $25 \mathrm{~kg}$ body weight through one parity. J. Anim. Sci., 79: 956-966.

Kurza J., Herzig I., Trávini če J., Il e k J., Kroupová V. (2010). Iodine and selenium contents in skeletal muscles of Red Deer (Cervus elephus), Roe Deer (Capreolus capreolus) and Wild Boar (Sus scrofa) in the Czech Republic. Acta Vet. Brno, 79: 403-407.

Mahan D.C., K i m Y.Y. (1996). Effect of inorganic or organic selenium at two dietary levels on reproductive performance and tissue selenium concentrations in first-parity gilts and their progeny. J. Anim. Sci, 74: 2711-2718.

Mahan D.C., Peters J.C. (2004). Long-term effects of dietary organic and inorganic selenium sources and levels on reproducing sows and their progeny. J. Anim. Sci., 82: 1343-1358.

Marin-Guzman J., Mahan D.C., Chung Y.K., P a t e J.L., P o pe W.F. (1997). Effects of dietary selenium and vitamin $\mathrm{E}$ on boar performance and tissue responses, semen quality, and subsequent fertilization rates in mature gilts. J. Anim. Sci., 75: 2994-3003.

O ls o n O.E. (1986). Selenium toxicity in animals with emphasis on man. Int. J. Toxicol., 5: 45-70.

P e chova A., S evcikova L., Pavlat a L., Dvorak R. (2012). The effect of various forms of selenium supplied to pregnant goats on selected blood parameters and on the concentration of Se in urine and blood of kids at the time of weaning. Vet. Med., 58: 394-403.

P olakova S. (2010). Obsah selenu (Se) v zemědělských půdách České republiky (The content of selenium (Se) in agricultural soils of the Czech Republic). Ústřední kontrolní a zkušební ústav zemědělský v Brně (ÚKZÚZ), 15 pp.

Shi o bara Y., You sh id a T., S u zu k i K.T. (1998). Effects of dietary selenium species on Se concentrations in hair, blood, and urine. Tox. Appl. Pharm., 152: 309-314.

Sochor J., Pohanka M., Ruttkay-Nedecký B., Zitka O., Hynek D., Mares P., Ze $\mathrm{m}$ a n L., A d a m V., K i z e k R. (2012). Effect of selenium in organic and inorganic form on liver, kidney, brain and muscle of Wistar rats. Cent. Eur. J. Chem., 10: 1442-1451.

Zduńczyk Z., Drazbo A., Jankowski J., Juskijewicz Z., Antoszkiewicz Z., Troszyńs ka A. (2013). The effect of dietary vitamin E and selenium supplements on the fatty acid profile and quality traits of eggs. Arch. Tierzucht, 72: 1-18.

Zeman L., Simecek K., Krasa A., Simek M., Loss man J., Trinacty J., Rudolfova S., Ves ely P., Hap I., Dolezal P., Kracmar S., Tvrznik P., M ichele P., Z e ma n o v a D., Siske V. (1995). Katalog krmiv (Feedstuffs). Pohořelice, Czech Republic, SPRINT Znojmo, $465 \mathrm{pp}$.

Zeman L., Dolezal P., Kopriva A., Mrkvicova E., Prochazkova J., Ryant P., S k la d a n k a J., S tra k ova E., S u c hy P., Ve s e ly P., Z e len k a J. (2006). Výživa a krmení hospodářských zvířat (Nutrition and feeding of livestock). Praha, Czech Republic, Profi Press, 360 pp.

Zhang Y., Zhu S., Wang X., Wang CH., Li F. (2011). The effect of dietary selenium levels on growth performance, antioxidant capacity and glutathione peroxidase 1 (GSHPx1) mRNA expression in growing meat rabbits. Anim. Feed Sci. Technol., 169: 259-264.

Received: 13 IX 2013

Accepted: 10 VI 2014 